\title{
Productivity, Seed Quality and Nutrient Use Efficiency of Wheat (Triticum aestivum) under Organic, Inorganic and Integrated Nutrient Management Practices after Twenty Years of Fertilization
}

\author{
S. SHEORAN ${ }^{1}$, D. RAJ ${ }^{1 *}$, R.S. ANTIL ${ }^{1,3}$, V.S. MoR ${ }^{2}$ and D.S. DAHIYA ${ }^{1}$ \\ ${ }^{1}$ Department of Soil Science, CCS Haryana Agricultural University, Hisar, Haryana 125004, India \\ ${ }^{2}$ Department of Seed Science and Technology CCS Haryana Agricultural University, \\ Hisar, Haryana 125004, India \\ ${ }^{3}$ Present address: Amity Food and Agriculture Foundation, Amity University Uttar Pradesh, \\ Noida-201313, UP, India
}

(Received 26 September 2016; Accepted 21 October 2016; Communicated by A. Aniol)

\begin{abstract}
A long-term field experiment started in 1995 on Research Farm of Department of Soil Science, CCS Haryana Agricultural University Hisar (India) was selected to study the effects of organic manures and chemical fertilizers on productivity, seed quality and nutrient use efficiency of wheat under pearl millet-wheat cropping system. The organic manures $(15 \mathrm{Mg}$ FYM, $5 \mathrm{Mg}$ poultry manure and $7.5 \mathrm{Mg}$ pressmud) were applied alone and in combination with fertilizers $\left(150 \mathrm{~kg} \mathrm{~N}+30 \mathrm{~kg} \mathrm{P}_{2} \mathrm{O}_{5} \mathrm{ha}^{-1}\right)$ and compared with chemical fertilizers applied alone $\left(150 \mathrm{~kg} \mathrm{~N}+60 \mathrm{~kg} \mathrm{P}_{2} \mathrm{O}_{5} \mathrm{ha}^{-1}\right.$ and $\left.75 \mathrm{~kg} \mathrm{~N}+30 \mathrm{~kg} \mathrm{P}_{2} \mathrm{O}_{5} \mathrm{ha}^{-1}\right)$. The results showed that the application of organic manures in combination with $\mathrm{N}$ and $\mathrm{P}$ fertilizers significantly increased all yield attributes, i.e. plant height, number of tillers $/ \mathrm{m}$ row length, spike length, number of grains/spike. Higher grain yield of wheat (61.4, 57.4 and $62.7 \mathrm{q} \mathrm{ha}^{-1}$ ) was observed when recommended dose of $\mathrm{N}$ and half of $\mathrm{P}$ was applied in conjunction with FYM, poultry manure and pressmud, respectively. Grain yield of wheat increased by 13.5, 6.1 and $15.9 \%$, respectively, under same treatments when compared with recommended dose of $\mathrm{N}$ and $\mathrm{P}$ fertilizers. Among the organic manures, highest yield $\left(32.9 \mathrm{q} \mathrm{ha}^{-1}\right)$ was obtained with pressmud application. However, application of organic manures alone resulted in poor yield and even lower than $50 \%$ recommended dose of $\mathrm{N}$ and $\mathrm{P}$ fertilizer. All the seed quality parameters (standard germination, shoot length, root length, seedling dry weight, seedling vigour index-I and -II) improved with the combined application of organic manures and chemical fertilizers as compared to their individual application. The partial factor productivity of $\mathrm{N}$ and $\mathrm{P}$ increased with combined application organic manures and chemical fertilizer as compared to chemical fertilizers applied alone, however, nutrient harvest index and their utilization efficiency decreased with combined application of organic manures and fertilizers as compared to their individual application.
\end{abstract}

Keywords: grain yield, yield attributes, seed quality, manures, nutrient use efficiency 


\section{Introduction}

Wheat (Triticum aestivum) is the second most important food crop in India (after rice) and occupies about 26.7 million hectares area and contributes about $33.9 \%$ of the total food grain production of country. This signifies the important contribution of wheat in meeting the food requirements of the country. The demand for wheat by 2050 is expected to increase by $31 \%$ over the 683 million tons consumed in 2008 (Dixon et al. 2009). Increasing wheat productivity is a national target to fill the gap between wheat consumption and production. Therefore, this is necessary to provide a good soil conditions for better growth of wheat crops in achieving high qualitative and quantitative yield. Seed is also an important component of agricultural production and availability of viable and vigorous seed at the planting time is very important for achieving the yield target (Peerzada et al. 2016).

The modern production system with indiscriminate use of chemical fertilizers and pesticides is facing a sustainability problem. Over the past decade India has exhibited a rapid uptake of organic farming. The application of ample amounts of organic manure is the key for success of organic farming. The continuous addition of organic manures to the soil not only increases its humus content year after year but also improves physical and chemical conditions by providing a favorable soil structure, enhancing soil cation exchange capacity, increasing the quantity and availability of plant nutrients and providing the substrate for microbial activities (Böhme and Böhme 2006). However, use of organic inputs in cropping system often has to deal with a scarcity of readily available nutrients in contrast to high input cropping system which relies on widely available soluble fertilizers.

Thus, soil fertility can be restored effectively through adopting the concept of Integrated Soil Fertility Management (Antil et al. 2011) encompassing a strategy for nutrient management based on natural resource conservation. Integrated use of organic and inorganic nutrient sources support to sustain yield and build up soil quality for enhanced production (Kumara et al. 2013; Brar et al. 2015). However, integrated use of organic manures like farm yard manure with mineral nitrogen sources is advocated due to its profound benefits. Keeping in view the importance of integrated use of organic manures and mineral fertilizers, present study was carried out with the objective to find out the relative performance of different organic manures and chemical fertilizers on yield, NPK uptake and their use efficiency by wheat in a pearl millet-wheat cropping system under semi-arid environment.

\section{Materials and Methods}

A long-term field experiment was initiated in 1995 at Research Farm of Department of Soil Science, CCS Haryana Agricultural University, Hisar, Haryana (India) to study the effects of various combinations of organic manures and chemical fertilizers on productivity and fertility of soil under pearl millet-wheat cropping sequence. The experimental site is located at $29^{\circ} 16^{\prime} \mathrm{N}$ latitude and $75^{\circ} 7^{\prime} \mathrm{E}$ longitude in north-west part of India. The climate of the area is semi-arid with a mean annual precipitation of $443 \mathrm{~mm}$ and mean an- 
nual temperature of $24.8^{\circ} \mathrm{C}$. The soil was coarse loamy, Typic Ustochrept. The physicochemical properties of surface soil $(0-15 \mathrm{~cm})$ analyzed at the start of experiment (1995) was as follows: $\mathrm{pH} 8.1$, EC $0.36 \mathrm{dSm}^{-1}$, OC 0.39 percent, and available N P K 196, 25.2, $434 \mathrm{~kg} \mathrm{ha}^{-1}$, respectively. The average nutrient composition of farmyard manure (FYM), poultry manure and pressmud applied in the experiment during past 20 years was as follows: OC 38.1, 25.2, and 49.6 percent, total N 1.2, 2.51, and 3.23 percent, total P 0.97, 1.82 and 1.10 per cent and total K 1.87,1.72, and 0.86 percent respectively. Since 1995, the following ten treatments with three replications were maintained on the permanent plots in randomized block design: $\mathrm{T}_{1}: 75 \mathrm{~kg} \mathrm{~N}+30 \mathrm{~kg} \mathrm{P}_{2} \mathrm{O}_{5} \mathrm{ha}^{-1}, \mathrm{~T}_{2}: 150 \mathrm{~kg} \mathrm{~N}+60 \mathrm{~kg}$

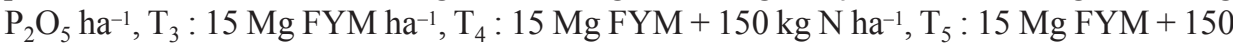
$\mathrm{kg} \mathrm{N}+30 \mathrm{~kg} \mathrm{P}_{2} \mathrm{O}_{5}$ ha $^{-1}, \mathrm{~T}_{6}: 5 \mathrm{Mg}$ poultry manure ha ${ }^{-1}, \mathrm{~T}_{7}: 5 \mathrm{Mg}$ poultry manure +150 $\mathrm{kg} \mathrm{N}+30 \mathrm{~kg} \mathrm{P}_{2} \mathrm{O}_{5} \mathrm{ha}^{-1}, \mathrm{~T}_{8}: 7.5 \mathrm{Mg}$ pressmud ha ${ }^{-1}, \mathrm{~T}_{9}: 7.5 \mathrm{Mg}$ pressmud $+75 \mathrm{~kg} \mathrm{~N}+30$ $\mathrm{kg} \mathrm{P}_{2} \mathrm{O}_{5}$ ha $^{-1}, \mathrm{~T}_{10}: 7.5 \mathrm{Mg}$ pressmud $+150 \mathrm{~kg} \mathrm{~N}+30 \mathrm{~kg} \mathrm{P}_{2} \mathrm{O}_{5}$ ha $^{-1}$. The plots are of $24 \times 5 \mathrm{~m}$ size.

The organic manures (FYM, poultry manure, pressmud) were applied once in a year at the time of wheat sowing. However, same dose of chemical fertilizers were applied to the succeeding crop pearl millet. The $\mathrm{N}$ and $\mathrm{P}$ were applied through urea and DAP, respectively. The wheat crop (cv. WH 1105) was sown on $23^{\text {rd }}$ and $26^{\text {th }}$ November, 2013 and 2014 , respectively and recommended package of practices were followed for growing the crops. The yield attributes, viz. plant height, number of effective tillers per meter row length, spike length, number of grains per spike and test weight of grains were recorded at the maturity of crop. Plant height, spike length and number of grain per spike were recorded from each plot at twenty randomly selected plants. Ear bearing tillers from $1 \mathrm{~m}$ row length at three places from each plot at maturity were counted and recorded as number of effective tillers per $m$ row length. For test weight, 1000-grains were counted from each treatment and then their weight was recorded.

Wheat crop was harvested manually with the help of sickle at about $2-3 \mathrm{~cm}$ above the ground level and biological yield of sun-dried bundles of each plot was recorded. The bundles were threshed and winnowed and grains so obtained were weighed. The straw yield was obtained by subtracting the grain yield from the biological yield. Seed quality parameters, viz. standard germination, root length, shoot length, seedling dry weight, seedling vigour index -I and -II were determined as par standard procedure of ISTA (2011). The plant samples collected at the time of crop maturity were dried in oven at $65 \pm 2{ }^{\circ} \mathrm{C}$ up to constant weight. Then the samples were grounded in a stainless steel grinder and stored in polythene bags for chemical analysis. Grain and straw samples were digested in di-acid mixture of $\mathrm{H}_{2} \mathrm{SO}_{4}$ and $\mathrm{HClO}_{4}$ in the ratio of 9:1 in digestion chamber. The digested plant samples were analyzed for total N, P, K contents and uptake of these elements were calculated by multiplying the nutrients content with yield. Total nitrogen was determined calorimetrically by using Nessler's reagent method (Lindner 1944). Phosphorus was determined by ammonium molybdovanadate yellow colour method (Koening and Johnson 1942) and potassium was determined by flame emission photometer in acid digested plant material. Nutrient harvest index was calculated by dividing nutrient uptake in seed with total nutrient uptake by crop and multiplied by hundred. The 
partial factor productivity (PFP) was calculated by dividing grain yield $\left(\mathrm{kg} \mathrm{ha}^{-1}\right)$ with amount of fertilizer nutrient applied $\left(\mathrm{kg} \mathrm{ha}^{-1}\right)$. Similarly, nutrient utilization efficiency was calculated by dividing grain yield $\left(\mathrm{kg} \mathrm{ha}^{-1}\right)$ with total nutrient uptake $\left(\mathrm{kg} \mathrm{ha}^{-1}\right)$.

Statistical analyses were accomplished using the program STATISTICA 6.0 Stat Soft, Inc. (2001). Within the STATISTICA 6.0 after calculating ANOVA, we have applied DUNCAN multiple-range test to compare significance differences within the treatments.

\section{Results}

\section{Yield attributes}

The pooled data of plant height, number of effective tillers per meter row length, spike length and number of grains per spike varied from 70.98 to $89.95 \mathrm{~cm}, 31.38$ to $81.92,7.80$ to $10.65 \mathrm{~cm}$, and 46.87 to 65.85 , respectively, under different treatment combinations of organic and inorganic source of nutrients. The yield attributes were lower when organic manures were applied alone, even lesser than half of recommended dose of NP fertilizers (Table 1). The combined application of organic manures and chemical fertilizers resulted in improved yield attributes over chemical fertilizer alone. The yield attributes were highest under the application of $\operatorname{pressmud}_{7.5} \mathrm{~N}_{150} \mathrm{P}_{30}$ and were statistically at par with $\mathrm{FYM}_{15} \mathrm{~N}_{150} \mathrm{P}_{30}$ treatment. However, under same treatment combination of poultry manure, only number of effective tiller was significantly lower than pressmud and FYM treatment combinations. Among the organic manures, best results were obtained with pressmud followed by FYM and poultry manure treatments.

\section{Grain and straw yield of wheat}

The grain yield of wheat varied from 26.1 to 57.1 and 25.7 to $68.3 \mathrm{q} \mathrm{ha}^{-1}$ under different treatment combinations of organic and inorganic sources of nutrients during 2013-2014 and 2014-2015, respectively. The lowest grain yield of wheat was recorded when either $15 \mathrm{Mg}$ FYM or $5 \mathrm{Mg}$ poultry manure or $7.5 \mathrm{Mg}$ pressmud ha- $\mathrm{h}^{-1}$ was applied alone (Table 1). When FYM were applied in combination with recommended dose of $\mathrm{N}$ fertilizer, a significant increase in yield was recorded over FYM applied alone which was statistically at par with recommended dose of NP fertilizers. The grain yield was further increased when half of recommended dose of $\mathrm{P}$ was also added. Highest pooled grain yield of wheat $\left(62.7 \mathrm{q} \mathrm{ha}^{-1}\right.$ ) was recorded with the application of $\operatorname{pressmud}_{7.5} \mathrm{~N}_{150} \mathrm{P}_{30}$ that was statistically at par with $\mathrm{FYM}_{15} \mathrm{~N}_{150} \mathrm{P}_{30}\left(61.4 \mathrm{q} \mathrm{ha}^{-1}\right)$. Grain yield of wheat increased by 118.5, 117.4 and 90.6 per cent with application of $15 \mathrm{Mg}$ FYM, $5 \mathrm{Mg}$ poultry manure and $7.5 \mathrm{Mg}$ pressmud ha ${ }^{-1}$ along with recommended $\mathrm{N}$ and half of recommended dose of $\mathrm{P}$ over manures applied alone, respectively. Similarly, grain yield of wheat increased by 13.5, 6.1 and 15.9 per cent under same treatments when compared with recommended dose of $\mathrm{N}$ and $\mathrm{P}$ fertilizers. Even after application of organic manures alone for 20 years in the same plot, the grain yield of wheat was significantly lower than that of 50 per cent recommended dose of NP fertilizers. 


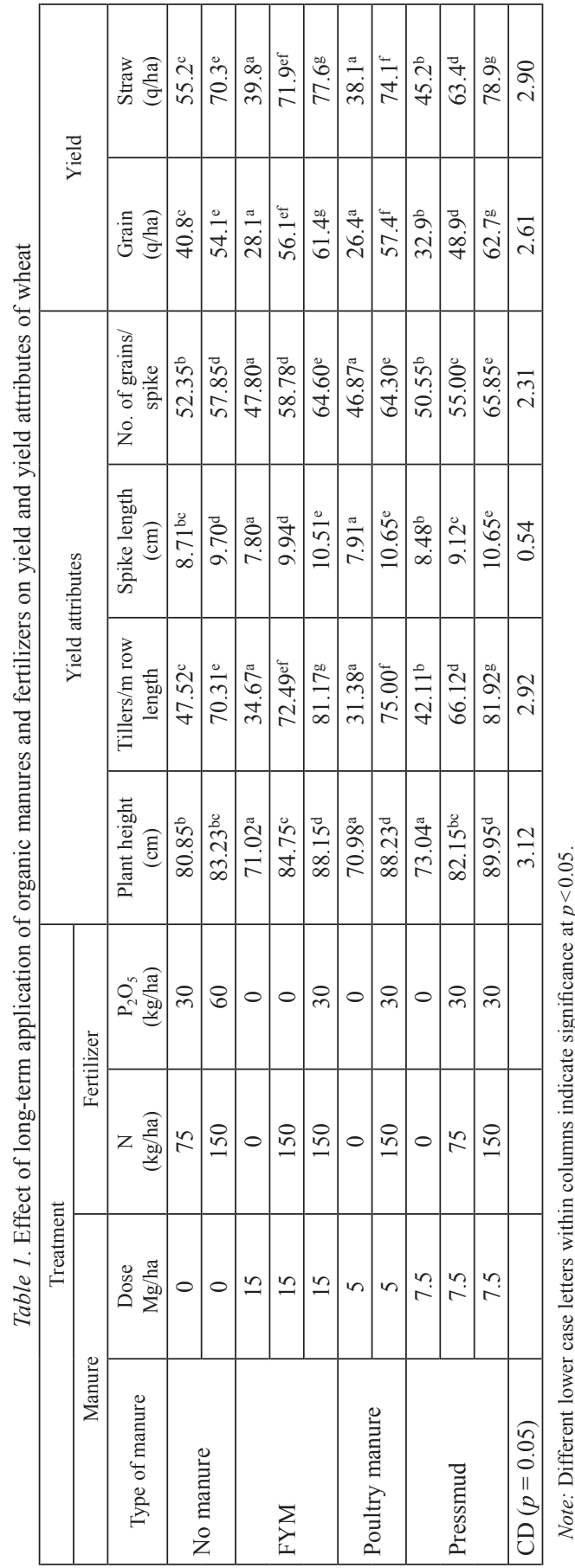

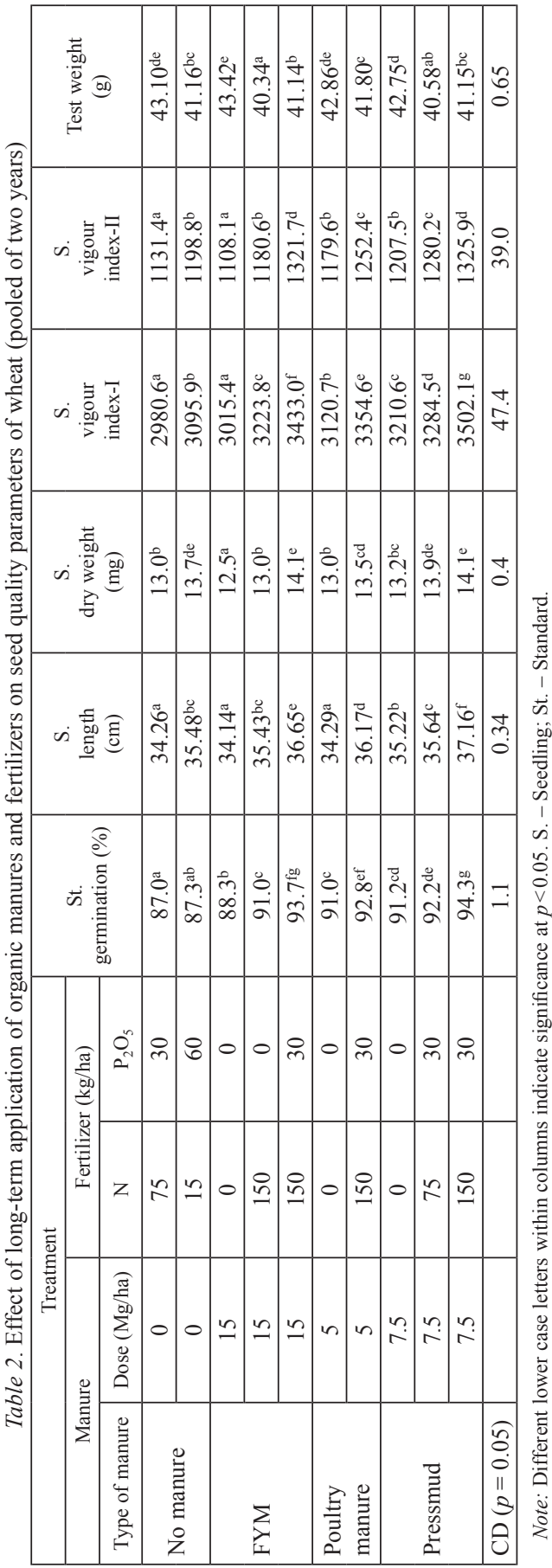

Cereal Research Communications 45, 2017 

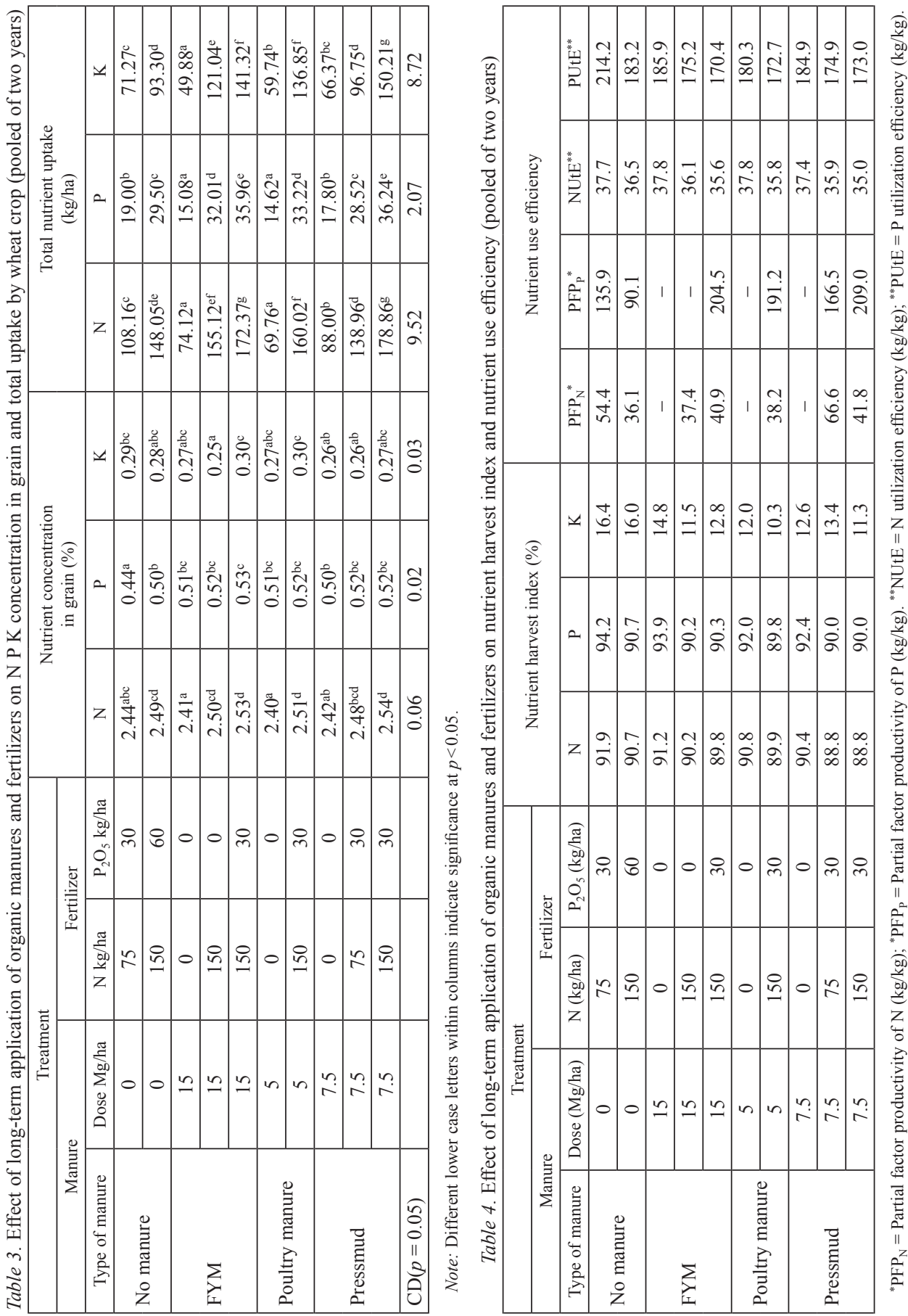
The straw yield of wheat followed the similar trend to that obtained by grain yield. The pooled straw yield ranged from $38.1 \mathrm{q} \mathrm{ha}^{-1}$ (poultry manure $_{5}$ ) to $78.9 \mathrm{q} \mathrm{ha}^{-1}$ (pressmud ${ }_{7.5} \mathrm{~N}_{150} \mathrm{P}_{30}$ ). There was an increase of about 94.9, 94.5 and 74.6 per cent in straw yield of wheat with application of $15 \mathrm{Mg}$ FYM, $5 \mathrm{Mg}$ poultry manure and $7.5 \mathrm{Mg}$ pressmud ha ${ }^{-1}$ along with recommended $\mathrm{N}$ and half of $\mathrm{P}$ over manures applied alone, respectively. Similarly, straw yield of wheat increased by 10.4, 5.4 and 12.2 per cent under same treatments when compared with recommended dose of $\mathrm{N}$ and $\mathrm{P}$ fertilizers. Harvest Index (HI) varied from 41.2 to 43.9 per cent and higher HI was observed under combined application of organic manures and fertilizers as compared to organic manures applied alone.

\section{Seed quality}

All seed quality parameters, i.e. standard germination, shoot and root length, seedling length, seedling dry weight, seedling vigour index-I and -II improved with combined application of organic manures and fertilizers as compared to their individual application (Table 2). Under different treatment combinations, pooled data of standard germination, shoot length, root length, seedling length, seedling dry weight, seedling vigour index-I and -II and test weight varied from 87.0 to 94.3 per cent, 9.28 to $10.50 \mathrm{~cm}, 24.25$ to 26.66 $\mathrm{cm}, 34.14$ to $37.16 \mathrm{~cm}, 12.5$ to $14.1 \mathrm{mg}, 2980.6$ to $3502.1,1108.1$ to 1325.9 , and 40.34 to $43.42 \mathrm{~g}$, respectively. All the seed quality parameters except test weight showed highest value under pressmud ${ }_{7.5} \mathrm{~N}_{150} \mathrm{P}_{30}$, while test weight was found highest under $\mathrm{FYM}_{15}$. Standard germination was significantly higher with application of pressmud and poultry manure alone as compared to recommended dose of chemical fertilizers applied alone. Among organic manures applied alone, higher values of all the seed quality parameters (except test weight) were observed with pressmud treatments followed by poultry manure and FYM.

\section{Nutrient concentration (NPK) and uptake by wheat crop}

Pooled data of nutrient concentration revealed that the organic manures applied alone were resulted lower NPK concentration in wheat grain. However, when organic manures were applied in conjunction with $\mathrm{N}$ or NP fertilizers, then only $\mathrm{N}$ concentration improved significantly. The N, P and K concentration in wheat grain ranged from 2.40 to $2.54 ; 0.44$ to 0.53 and 0.25 to 0.30 per cent, respectively under different treatment combinations (Table 3). Among all the treatments, highest (2.54 per cent) and lowest ( 2.40 per cent) $\mathrm{N}$ concentration in wheat grain was observed with pressmud ${ }_{7.5} \mathrm{~N}_{150} \mathrm{P}_{30}$ and poultry manure ${ }_{5}$, respectively. The $\mathrm{P}$ concentration in wheat grain was highest ( 0.53 per cent) and lowest (0.44 per cent) with application of $\mathrm{FYM}_{15} \mathrm{~N}_{150} \mathrm{P}_{30}$ and $\mathrm{N}_{75} \mathrm{P}_{30}$, respectively. The highest $\mathrm{K}$ concentration ( 0.30 per cent) in wheat grain was observed in $\mathrm{FYM}_{15} \mathrm{~N}_{150} \mathrm{P}_{30}$ and poultry manure ${ }_{5} \mathrm{~N}_{150} \mathrm{P}_{30}$ treatments, while lowest ( 0.25 per cent) was observed in $\mathrm{FYM}_{15} \mathrm{~N}_{150}$.

The results showed that $\mathrm{N}, \mathrm{P}$ and $\mathrm{K}$ concentration in wheat straw ranged from 0.16 to $0.26 ; 0.020$ to 0.046 and 1.07 to 1.99 per cent, respectively. The highest ( 0.26 per cent) and lowest $\left(0.16\right.$ per cent) $\mathrm{N}$ concentration was found in pressmud ${ }_{7.5} \mathrm{~N}_{150} \mathrm{P}_{30}$ and $\mathrm{N}_{75} \mathrm{P}_{30}$, respectively. In contrast to wheat grain, $\mathrm{P}$ concentration in wheat straw was highest $(0.046$ 
per cent) with poultry manure ${ }_{5} \mathrm{~N}_{150} \mathrm{P}_{30}$ and pressmud ${ }_{7.5} \mathrm{~N}_{150} \mathrm{P}_{30}$ that was statistically at par with $\mathrm{FYM}_{15} \mathrm{~N}_{150} \mathrm{P}_{30}(0.045$ per cent $)$ treatment. Highest $\mathrm{K}$ concentration in wheat straw (1.99 per cent) was noticed in poultry manure ${ }_{5} \mathrm{~N}_{150} \mathrm{P}_{30}$ and lowest (1.07 per cent) where FYM was applied alone.

The total N, P and K uptake by wheat crop varied from 69.76 to $178.86 ; 14.62$ to 36.24 and 49.88 to $150.21 \mathrm{~kg} \mathrm{ha}^{-1}$, respectively, among different treatment combinations (Table 3). The lowest total $\mathrm{N}$ and $\mathrm{P}$ uptake was observed with application of poultry manure alone, while lowest $\mathrm{K}$ uptake was observed with the application of FYM alone. The highest total N, P, K uptake was observed with application of pressmud ${ }_{7.5} \mathrm{~N}_{150} \mathrm{P}_{30}$. Among organic manures, highest $\mathrm{N}, \mathrm{P}$ and $\mathrm{K}$ uptake by wheat crop was observed where only pressmud (88.00, 17.80 and $66.37 \mathrm{~kg} \mathrm{ha}^{-1}$, respectively) was applied. Total $\mathrm{N}, \mathrm{P}$ and $\mathrm{K}$ removed by wheat crop was higher when organic manures were applied in conjunction with NP fertilizers. With the application of $\mathrm{FYM}_{15} \mathrm{~N}_{150} \mathrm{P}_{30}$, poultry manure ${ }_{5} \mathrm{~N}_{150} \mathrm{P}_{30}$ and pressmud $_{7.5} \mathrm{~N}_{150} \mathrm{P}_{30}$, the $\mathrm{N}, \mathrm{P}$ and $\mathrm{K}$ uptake by wheat crop was increased by $16.4,8.1$ and 20.8 per cent, $21.9,12.6$ and 22.8 per cent and $51.5,46.7$ and 61.0 per cent, respectively, over application of recommended dose of $\mathrm{N}$ and $\mathrm{P}$ fertilizers.

\section{Nutrient harvest index and nutrient use efficiency}

Nutrient harvest index reflects the ability of plant to transfer nutrient from shoot to grains. Nitrogen, phosphorus and potassium harvest index (NHI, PHI, KHI) varied from 88.8 to $91.9,89.8$ to 94.2 and 10.3 to 16.4 per cent, respectively, under different treatment combinations (Table 4). With the application of full dose of chemical fertilizers, the NHI, PHI and KHI was lower than half dose of recommended chemical fertilizer. The nutrient harvest index decreases with combined application of organic manures and chemical fertilizers as compared to that obtained by application of organic manures and fertilizers alone. The higher PHI was observed where only organic manures was applied as compared to that observed under recommended dose of chemical fertilizers, however, reverse trend was observed in case of KHI and there was no much difference in NHI. The partial factor productivity of nitrogen $\left(\mathrm{PFP}_{\mathrm{N}}\right)$ and phosphorus $\left(\mathrm{PFP}_{\mathrm{P}}\right)$ varied from 36.1 to 66.6 and 90.1 to $209.0 \mathrm{~kg} \mathrm{~kg}^{-1}$ nutrient applied, respectively, under different treatments (Table 4). The highest $\mathrm{PFP}_{\mathrm{N}}$ and $\mathrm{PFP}_{\mathrm{P}}$ of wheat was observed in pressmud ${ }_{7.5} \mathrm{~N}_{75} \mathrm{P}_{30}$ and pressmud ${ }_{7.5} \mathrm{~N}_{150} \mathrm{P}_{30}$, respectively. However, their value was lowest when recommended dose of chemical fertilizers were applied. Combined application of fertilizers along with $15 \mathrm{Mg}$ FYM or $5 \mathrm{Mg}$ poultry manure or $7.5 \mathrm{Mg}$ pressmud ha ${ }^{-1}$ increased the PFP of $\mathrm{N}$ and $\mathrm{P}$ as compared to NP fertilizers applied alone. Nutrient utilization efficiency is ability of crops to convert adsorbed nutrient into yield and in the present study, the nitrogen and phosphorus utilization efficiency ranged from 35.0 to 37.8 and 170.4 to $214.2 \mathrm{~kg} \mathrm{~kg}^{-1}$ nutrient uptake under different treatments combinations. Highest and lowest NUtE was observed with $\mathrm{FYM}_{15}$ or poultry manure ${ }_{5}$ and pressmud ${ }_{7.5} \mathrm{~N}_{150} \mathrm{P}_{30}$, respectively, while, highest and lowest PUtE was observed with $\mathrm{N}_{75} \mathrm{P}_{30}$ and $\mathrm{FYM}_{15} \mathrm{~N}_{150} \mathrm{P}_{30}$, respectively. Combined application of fertilizers and organic manures resulted in lower NUtE and PUtE as compared to organic manures and fertilizers applied alone. 


\section{Discussion}

All the yield attributes increased with the combined application of organic manures and fertilizers. Increase in plant height may be due to the stimulation of cell division and internodes elongation resulted from nitrogen application. Similarly, increase in spike length may be attributed to the role of nitrogen in promoting the vegetative growth and merismatic activity during growth (Zaki et al. 2012). Similar type of results was also reported by Dekhane et al. (2015). Application of organic manures alone resulted in poor yield attributes because organic manure alone cannot fulfill the nutrient demands of crop. Continuous application of organic manures alone for 20 years in the same field could not able to produce the yield level as produced by recommended dose of chemical fertilizers. This may be due to continuous loss of mineralized $\mathrm{N}$ from the soil by leaching and volatilization processes and reduced the nitrogen use efficiency. Thus, $\mathrm{N}$ cannot be saved with the application of any type of organic manures. The higher yield of wheat observed with the application of pressmud over other manures may be due to better soil quality developed with pressmud application which was indicated by higher microbial biomass carbon, formation of more humic substances and deposition of lesser soluble salts (data not shown). The pooled data revealed that the grain and straw yield of wheat under different combinations of organic and inorganic source of nutrients follow the trend as: pressmud $>$ FYM > poultry manure, respectively. The supply of plant nutrient (fertilizers) and nutrients mineralized from organic manures meet the need of the crop slowly but continuously along with readily available macro and micronutrients which resulted in better plant canopy. Consequently, the higher rate of photosynthesis resulted in increased productivity. Narwal et al. (2005) and Brar et al. (2015) also reported the superiority of combined application of FYM and recommended dose of chemical fertilizers in increasing the productivity of pearl millet-wheat cropping system compared to application of recommended dose of chemical fertilizers alone.

All the seed quality parameters improved with the combined application of manures and fertilizers over their individual application. The improved seed quality is due to better filled seeds with higher protein content as indicated by higher $\mathrm{N}$ content in the seed (Table 3). The increase in seed quality with the combined application of organic manures and fertilizers may also be due to accumulation of higher quantities of seed constituents like carbohydrate in the seed under well-nourished conditions thus gave bold, good quality and vigorous seeds (Raissi et al. 2012). The results of present study are the conformity of previous findings of several researchers (Channabasanagowda et al. 2008; Peerzada et al. 2016).

Conjunctive use of organic manures and chemical fertilizers resulted in increase of $\mathrm{N}$, $\mathrm{P}$ and $\mathrm{K}$ concentration and uptake due to the improvement in soil properties which resulted better absorption of water and nutrients from native as well as applied sources (Antil et al. 2011; Brar et al. 2015). The increase in uptake of nutrients with integrated use of FYM and fertilizers have also been reported by several workers (Chesti et al. 2013; Parmer 2014). In present study, pressmud application with low $\mathrm{C}: \mathrm{N}$ ratio and high $\mathrm{N}$ content tended to decompose faster and release nutrients for crop uptake. While Bahadur 
et al. (2013) reported that NPK uptake was higher with application of FYM as compared to that of pressmud and compost, which might be due to variation in their nutrient composition and their release pattern in soil.

The reduction of $\mathrm{N}, \mathrm{P}$ and $\mathrm{K}$ harvest indices would increase the efficiency of nutrient use and reduce the removal of nutrients from agricultural systems, thereby contributing to a more sustainable land use (Araujo and Teixeira 2003). The PFP of N and P increased with combined application of organic manures and fertilizers because manures reduced the losses of nutrients and increased their availability in soil and hence they are more utilized by the crop plants. Similar results were also reported by Vukovic et al. (2008). Several studies indicated that a decrease in NUE with increasing fertilizer rates is because grain yield rises less than the $\mathrm{N}$ supply in soil by fertilizer application (Lopez-Bellido and Lopez-Bellido 2001). Similar to NUE, increase in nitrogen fertilizer dose also decreased the nitrogen utilization efficiency. The results are in conformity with results of Haile et al. (2012), who reported that $\mathrm{N}$ utilization efficiency (NUtE) was decreased with increased fertilizer application rates. In the present study, increased in grain yield decreased NUtE and vice varsa, while, Muurinen et al. (2007) concluded that increasing grain yield increased NUtE and also reported a strong relationship between NUtE and grain yield.

All these results clearly depict that combined application of organic manures and chemical fertilizers not only gave better yield, seed quality, and partial factor productivity but also lowered the nutrient harvest index and nutrient utilization efficiency as compared to organic manures and fertilizers applied alone. All these facts draw the conclusion that more focus should be given to combined application of organic manures and chemical fertilizers that helps in sustainable production and environment friendly conditions.

\section{Acknowledgement}

Authors are highly thankful to Dr. (Mrs) Poonam Mor Assistant Professor Department of Haryanvi culture and Languages CCS HAU Hisar for language editing of the manuscript.

\section{References}

Araujo, A.P., Teixeira, M.G. 2003. Nitrogen and phosphorus harvest indices of common bean cultivars: Implications for yield quantity and quality. Plant Soil 257:425-433.

Antil, R.S., Narwal, R.P., Singh, B., Singh, J.P. 2011. Integrated nutrient management for sustainable soil health and crop productivity. Indian J. Fert. 7:14-32.

Bahadur, L., Tiwari, D.D., Mishra, J., Gupta, B.R. 2013. Nutrient management in rice-wheat sequence under sodic soil. J. Indian Soc. Soil Sci. 61:341-346.

Böhme, L., Böhme, F. 2006. Soil microbiological and biochemical properties affected by plant growth and different long-term fertilization. European J. Soil Biol. 42:1-12.

Brar, B.S., Singh, J., Singh, G., Kaur, G. 2015. Effects of long term application of inorganic and organic fertilizers on soil organic carbon and physical properties in maize-wheat rotation. Agron. 5:220-238.

Channabasanagowda, N.K., Patil, B., Patil, B.N., Awaknavar, J.S., Ninganur, B.T., Hunje, R. 2008. Effect of organic manures on growth, seed yield and quality of wheat. Karnataka J. Agric. Sci. 21:366-368.

Chesti, M.H., Kohli, A., Sharma, A.K. 2013. Effect of integrated nutrient management on yield of and nutrient uptake by wheat and soil properties under intermediate zone of Jammu and Kashmir. J. Indian Soc. Soil Sci. 61:1-6. 
Dekhane, S.S., Patil, N.B., Jadhav, K.P., Patel, D.J. 2015. Effect of organic and inorganic fertilizers on growth and yield of paddy. Int. J. Trop. Agric. 33:149-151.

Dixon, J., Braun, H.J., Crouch, J. 2009. Transitioning wheat research to serve the future needs of the developing world. In: Wheat Facts and Futures. International Maize and Wheat Improvement Centre (CIMMYT), DF, Mexico.

Haile, D., Nigussie, D., Ayana, A. 2012. Nitrogen use efficiency of bread wheat: Effects of nitrogen rate and time of application. J. Soil Sci. Plant Nut. 12:389-409.

ISTA 2011. International rules for seed testing. International Seed Testing Association. Baserdorf, Switzerland.

Koening, R.A., Johnson, C.R. 1942. Colorimetric determination of phosphorus in biological materials. Ind. Eng. Chem. Anal. 14:155-156.

Kumara, B.H., Antil, R.S., Dev Raj. 2013. Long term effects of nutrient management on soil health and crop productivity under Pearl millet-wheat cropping system. Indian J. Fert. 9:86-97.

Lindner, R.C. 1944. Rapid analytical methods for some of the more common inorganic constituents in plant tissue. Plant Physiol. 19:76-86.

Lopez-Bellido, R.J., Lopez-Bellido, L. 2001. Efficiency of nitrogen in wheat under Mediterranean condition: Effect of tillage, crop rotation and $\mathrm{N}$ fertilization. Field Crops Res. 71:31-64.

Muurinen, S., Kleemola, J., Peltonen-Sainio, P. 2007. Accumulation and translocation of nitrogen in spring cereal cultivars differing in nitrogen use efficiency. Agron. J. 99:441-449.

Narwal, R.P., Antil, R.S. 2005. Integrated nutrient management in pearl millet-wheat cropping system. In: Kapoor, K.K., Sharma, K.K., Dudeja, S.S., Kundu, B.S. (eds), National Symp. on Management of Organic Wastes for Crop Production. Department of Microbiology, CCS Haryana Agricultural University. Hisar, India. pp. 205-213.

Parmer, D.K. 2014. Yield, produce quality and soil health under vegetable cropping systems as influenced by integrated nutrient management in mid-hill zone of Himachal Pradesh. J. Indian Soc. Soil Sci. 62:45-51.

Peerzada, O.H., Mor, V.S., Abhinav, D., Axay, B., Dahiya, O.S., Pandey, V., Anzer, U.I., Mohammad, S.R. 2016. Influence of integrated nutrient management on seed quality of fenugreek (Trigonella Foenumgraecum L.). Environ. Eco. 34:2226-2230.

Raissi, A., Galavi, M., Ramroudi, M., Mousavi, S.R., Rasoulizadeh, M.N. 2012. Effects of phosphatebio-fertilizer, organic manure and chemical fertilizers on yield, yield components and seed capabilities of isabgol (Plantago ovate). International J. Agri. Crop Sci. 4:1821-1826.

Vukovic, I., Mesic, M., Zgorelec, Z., Jurisic, A., Sajko, K. 2008. Nitrogen use efficiency in winter wheat. Cereal Res. Commun. 36:1199-1202.

Zaki, N.M., Gomaa, M.A., Radwan, F.I., Hassanein, M.S., Wali, A.M. 2012. Effect of mineral, organic and bio-fertilizers on yield, yield components and chemical composition of some wheat cultivars. J. Appl. Sci. Res. 8:174-191. 